\title{
The Position of Population of Biladelsham (The Levant) on the Islamic Conquests
}

\author{
Dr. Mohammad Fayyad Al- Azzi \\ Mafraq - Jordan
}

\begin{abstract}
This study highlights the attitude of the population - refers herein to the people who settled in the Levant; both the nomadic or settled Arab tribes and city dwellers like Byzantines, Jews and Christians- of the Levant to the Islamic conquests. It also highlights the reasons for these differing and changing attitudes to the Arab conquerors and the key rolethe Arab tribes inhabiting the Levant played in facilitating the conquest. In addition, it focuses on why they changed their destination from the Byzantine Empire to the Arab conquerors despite their faith differences, as well as, the reasons why Jewish minorities in the Levant preferred Arab Muslims to Byzantine rule.
\end{abstract}

Keyword: tribes , conquest ,Arabs,Byzantiun ,battle

Previous studies

Some researchers have touchedon the Christian Arab tribes and the population settled in the Levant in their studies, like a study entitled Alqaba'el Alarabiyah Almutanasirah (Christian Arab Tribes), by a researcher called Mohammed Khreisat who addressed thespread of these tribes over the Levant, without referring to the attitude of the other people of the Levant to the Islamic conquest,and Mawqif Sokkan Bilad Elsham Min Alfath(The Position of the People of the Levant on the Conquest) by a researcher called NabihAqil, who touched on the attitude of the people to the conquest in general, without demonstrating the position of the Christian clergies and the Levant Nabateanson the conquest. However, both the studies were highlyvaluableto the study.

\section{The study approach}

The study adoptedan analytical and inductive approach, which most of the historical studies depend on, and was based on various historical sources, modern references and other studies.

\section{Introduction}

The pre-Islamic spread of Arab tribes throughout the vast territory of the Levant impacted the Islamic conquests. The attitudes of the tribes to the hostilities that broke out between Muslim conquerors and Roman armies varied, a number of tribes took the side of the Arab conquerors,butothers took the side of the Romans.As for the local population, some sided with the Romans, whilst others remained fearful, waiting for who prevails, whereas the Jewish minorities welcomed the Arab conquerors not because they loved them but because they hated Christianity.

-First Subject- Population of BiladElsham pre- Islam conquest .

The Near East before the coming of Islam was dominated, by two great empires, Roman - Byzantine to the west and Persian to the east. The frontier between tow empire had fluctuated considerably during this time (1).

In the century before Islamic conquest, Arab nomad tribes had penetrated in to previously settled area in northern Syria Aleppo and Qinnasrin, hi the lands to the east of the Jordan and southern borders of Palestine. In addition much of the population of such cities as Damascus and Homs on the edge of the desert was of Arab origin. Some divisions between Arab and non- Arab in these area were blurred and while we can probably assume that most of the nomadic pastoralists in the area were Arabic speakers, so too were the inhabitants of some of the settled areas ${ }^{(2) .}$

Some region by contrast seem to have been almost completely unaffected by Arab immigration before the coming of Islam These include the alluvial plains of southern Iraq known as the Sawad, the mountain and the coastal area of Palestine and Syria and in the north .These Arabic - speaking population were united by a common language and the idea of a common kinship ${ }^{(3)}$.

(1) Hugh Kennedy ,the Prophet and the Age of Caliphates, Longman London and New York ,p.1.

(2) Hugh Kennedy, op. cit,p.16

$\left({ }^{3}\right)$ Hugh Kennedy ,op. cit,p.16 
Despite this linguistic and ethnic unity, the Arabs were no central political organization or administration . In previous centuries there were Arab kingdoms with some form of government but these was usually on fringes of the Arab lands and under the patronage or protection of outside powers ${ }^{(4)}$.

\section{Second Subject: The Position of Christian Arab Tribes:}

Many tribes settled in the Levant before Islam, and their positionssplitup into three:a party whose faithwas like Arabs stood byMuslims, another whose faith was Christianitystood by Arabs, and the third onethatwas Christians in name adopted a position of neutrality with inclination forArabs and said: "We hate to fight our brothers in faith - the Christians, and we hate to help Non-Arabs on our people - Arabs. ${ }^{(5) "}$

Verily, the conquests have revealed these tribes' attitudes; when Caliph Abu Bakr ordered Khalid IbnSaiidIbnAla'as to head towards Taima'a and to urge that the surrounding tribes join him, hordes of people subsequently gathered for alliance. But when the Romans found out, they sought help from the Levant's Arabtribes allied with them. Thus, Khalid IbnSaiidwrote to the Caliph who replied: "Go ahead and ask help from Allah."When he approached them, they dispersed and left their homes, and finally most of the people who congregated around him embraced Islam ${ }^{(6)}$.

In fact, the positions of these tribes on the conquest varied; once AmrIbn Al As marched to conquer Palestine, he encountered no resistance on his way from Hijaz until he reached WadiAraba ${ }^{(7)}$.Byzantiun benefited from the Arabs it is allied with. So, it hired them to spy upon the Arab conquerors; in the early battles of the Islamic conquest of Palestine when both sides faced each other, the Roman commander sent an Arab man from Quta'a to covertly break through Muslim combatants tospend a day and a night collecting informationabout the people for him. The man, dressed up as an Arab, then infiltrated into the Muslims, and after a day and a night came out with the news of Muslims ${ }^{(8)}$.

For the Romans in the opposite side, some Christian tribes in the south of the Dead Sea supported the conquest armies. They had been loyal to Byzantium, receiving constant financial aids from them and having previously taken sides with them in Mu'tah battle. BecauseHeraclius suspended the aids subsequent to that battle due to his desperate need for money after his wars with the Persians, these tribes changed their destination from Byzantium. In the view of the Roman historian Theovas, the suspension of aid to these tribes made them support Muslims and change their position (9).

In the battle of Ajnadeen, the positions of theChristian Arab tribes varied. During abuObeida's raids on the outskirts of Damascus, Khalid Ibn Al-walid and Abu Obeida learned that a crowd of Romans had descended on Ajnadeenfrom Palestine, and that the people of the city and the Arab Christians whom they passed by had rushed to them ${ }^{(10)}$. While some others declared their support for the Muslims in the battle of Fahal, where a large number of Lakham, Jutham, Ghassan, and other tribes stood by Muslims, who grew stronger against the Romans due to their support ${ }^{(11)}$.

In Jordan, where its cities were conquered without much struggle, many tribes showed little resistance ${ }^{(12)}$, thanks to the presence of the tribes of Ghassan, A'amila and Belkin ${ }^{(13)}$. In Palestine, most of its cities were conquered in exchange for an assurance of safety on their lives and their homes, and for paying tribute andKharj (tax) on their land ${ }^{(14)}$.

When Heraclius marched to confront the Muslims in Yarmouk, there was a large crowd of Arab tribes with him, and there were about twelve thousand led by JibillaIbn Al-ayham Al-ghasani ${ }^{(15)}$.

$\left({ }^{4}\right)$ Hugh Kennedy ,op. cit,p.16

(5)Alazdi, Mohammed Ibn Abdullah (died. 170- 175 AH / 786-791 AD), FottouhEl Sham, innot,Essam Mustafa Oqla, Yousef Ahmed BaniYassin, Hamada Foundation for University Studies, Irbid, Jordan 2005. , P. 266. Khreisat, Mohamed Abdel-Kader, Dawr El Arab Almutanasira Fe El Fotouhat, the Fourth International Conference of the history of the Levant, the second seminar, vol. II, p. 149 ..

(6)Alttabari, Abu Jafar, Muhammad IbnJarir (died. 310 AH / 922 AD), TareekhAlrosolWalMolouk, chap10, innot: Abou El Fadl Ibrahim, Dar Alma'aref, $2^{\text {nd }}$ ed, chap. 3, pp. 388- 389. Khuraisat,op. cit , p. 151 .

(7)Al-Baladhuri, Ahmed IbnYahya Al-Baladhuri (died. 279 AH / 892 AD) FottouhEl Boldan, innot: Mohammed Radwan, Dar AlkotobAlilmiyah, Beirut, Lebanon, 1983, p. 117.

(8)Khammash, Nejdah, Al-sham Fe Sadr El Islam, Dar Tlassfor Studies, Translation and Publishing, Damascus, $1^{\text {st }}$ ed, 1987 , pp. 66- 67.

(9)Nöldeke, Theodore, Umera'aGhassan, translated by Constantine Zurayk, Beirut 1939. p. 49.

(10)Alazdi, op. cit., p. 169.

(11)Alazdi, op. cit., p. 199.

(12)Al-Baladhuri, FattouhEl Boldan, p.123, QudamahIbnJaafar (329 AH / 940 AD), AlkharajWaSena'at El Ketabah, explained commented by: Mohammed Hussein al-Zubaidi, the Ministry of Culture and Information, Iraq, 1981, p. 290.

(13)Khuraisat, op. cit., p. 153.

(14)Al-Baladhuri, op. cit., p. 144.

(15)Alttabari,op. cit., chap. 3, p. 570. 
Apparently, he then sided with the Muslims, saying: "You are our brothersand the sons of our father", and he claimed that he converted to Islam ${ }^{(16)}$. On the other hand, a number of Lakham and Jutham tribes joined the Muslims, but when they realized the seriousness of the fight, they fled and let the Muslims down ${ }^{(17)}$. The Islamic conquests also revealed that the Romans forcefully pushed some Arab tribes to wage war alongside them; when, the Muslim commander, Abu Obeida sent his general, Khalid Ibn Al-walid, to Qinserin after the conquest of Homs, and after Khalid arrived the area of Alhadhir ${ }^{(18)}$, the Romans marched towards them. Next, the people of Alhadhir sent to Khalid, telling him that they were Arabs and were forced to fight, he believed what they said and pardoned them ${ }^{(19)}$. With regard to the Nabataeans of the Levant, Muslims have hired them as spies upon the Romans for a fee ${ }^{(20)}$.

The affiliation of the Arab Christians was directly proportional to every victory achieved by Muslims over the Romans, so, the Muslims benefited from them in intelligence for espionage purposes. Accordingly, during the stage of mobilization, prior to the battle of Yarmouk, and right after the Romans had taken their positions, the Muslims pushed some of the townsmen who had become good Muslims to infiltrate by stealth through the Romans to fill them in with their news ${ }^{(21)}$.After the battle of Yarmouk, many of the ChristianArabs stood by the Muslims, and fought alongside them in the cities of Homs and Aleppo ${ }^{(22)}$, Qanserin and Bals ${ }^{(23)}$, where Abu Obeida settled Arabs who were in the Levant and who converted to Islam after the conquest, and other people that were not from the missions and that came from the tribe of Qais in the beduin countryside ${ }^{(24)}$. They preferred blood relationship and Arabism to faith attachments and helped the Muslims ${ }^{(25)}$.

As made clear by the foregoing, it wasnormalfor these Christians not to take sides with the conquering Arabs from the outset, because things had been unclear. So, they remained allied to the Romans, as for them the Muslims' conquest didn't seem stable. However, when they realized that these people had come preaching a new religion, and when they felt what the Arabs had shown of religious tolerance and the low taxes they had imposed, they saw the Muslims as their saviors ${ }^{(26)}$.

\section{The Third Subject: The Position of the Residents of Cities and Villages on the Islamic Conquest}

Caliph Abu Bakr was keen in his commandments to urge the leaders of the Levant conquest to focus on conquering villages and rural areas at the beginning and avoid cities, in order to prevent a big clash with the Romans in the first phase of conquest -the movement of the armies of conquest showed us that the horses of the early conquerors didn't set foot on the big cities of Damascus, since the Byzantine forces and their friendly local population took them as a residence ${ }^{(27)}$ and that the villagers and rural areas inhabitants who spoke Arabic due to blood relationships and relations by marriage with the Arab tribes were less hostile. Thus, the first clash between the Arab conquerors and the inhabitants of the Levant was a clash between two parties bonded by blood and sharing the same language. Nevertheless, one of the positions of the settled villagers, who lived a life of stability not a life of nomadism ${ }^{(28)}$, was the one of Fahal Christians who wrote to Muslims, arguing that the Muslims were more beloved to them than the Romans, and Muslims were more sincere and merciful, even though they had the same religion, and the Romans had prevailed over them and their homes. However, the Muslims demanded that they go under their protection, but their attitude was fearful and they claimed sincerity,waiting for the outcome of the war and how things would turn out for the Romans after the war ${ }^{(29)}$.

(16)Al-Baladhuri, op. cit., pp. 137- 138.

(17)Cf.Alazdi, op. cit., pp. 333- 334.

(18)Alhadhir: A place located near Allepo, where Arab tribes settled, YaqoutAlhamwi, ShihabAlddinAlrumi (died. 626 AH / 1228 AD), Mu'jamElboldan, Dar Saddir- Beirut, $2^{\text {nd }}$ ed, 1995, chap. 1, p. 206.

(19)Alttabari, op. cit., chap. 3, p. 601.

(20)Alazdi, op. cit., p. 172.

(21)Alazdi, op. cit., p. 272.

(22)Khuraisat, op. cit., p. 151.

(23)Balis: a town in the Levant between Allepo and Raqqa. YaqoutAlhamawi, op. cit., chap. 1, p. 321.

(24)Al-Baladhuri,op. cit.,p. 151.

(25)Khuraisat, op. cit., p. 152.

(26)Abbas, Ihsan, TareekhBiladEsham, the University of JordanPress, Amman - Jordan, 1990, p. 183.

(27)NabihAqil, MawqifSokkanBiladElsham Min Alfath. Fourth International Conference on the history of the Levant,

BiladEsham Fe Sadr El Islam, vol. III, University of Jordan, Amman, Jordan, 1987, p. 152.

(28)NabihAqil, op. cit., p. 152.

(29)Alazdi, op. cit., p. 199. 
Things became clear after the defeat of Romans in the battle of Fahl. They sued for peace for tribute; whoever wishes to follow the Romans and leave Jordan was allowed to, and so was whoever wishes to stay in Jordan provided that they pay tribute. The peace agreement was accordingly made ${ }^{(30)}$.

Christian clerics regarded the Arab conquerors' conflict to be a struggle of life and death. After the Romans realized that it was not an invasion of tribes that came for plunder, they brought to their decisive battle with the conquering Arabs horses and men, led by senior clerics, urging them to fight ${ }^{(31)}$. They were their spiritual weapon in the battle, instilling enthusiasm in the army, because the defeat of Byzantium in their view is the end of Christianity ${ }^{(32)}$. They would say: "Even though we see no good day coming, we don't wish to see a fateful day ${ }^{(33)}$.

Heraclius was so religious that he wanted to reconcile with the Muslims, but his courtiers said to him: "Fight for your religion and do not discourage the people and do what you have to do...)" (34). Not only the clerics, but also the Christians all over the cities of the Levant developed this attitude, but with variationamong the cities of the north and the south, near or far from Hijaz and Byzantium, which is normal that the attitude of the clergy and that of the people at large was in single-hearted unity ${ }^{(35)}$. The cities of Homs, Damascus, Gaza, Beit al-Maqdis, Bosra, Amman, Jerash and the coastal cities managed to withstand since they were the strongholds of the Romans, as the conquering Arabs initially avoided dealing with the cities and paid greatest attention on rural areas and villages in order to speed up the conquest and left the cities to later stages ${ }^{(36)}$. The city of Damascus, for instance, was able to withstand the Muslims for seventy days,expectingreinforcements byHeraclius, and when they realized that there was no hope of reinforcements, their resolve weakened and accepted reconciliation after the Islamic Army entered the city, which was in a state of panic and fear ${ }^{(37)}$, as did the city of Homs, which had remained closed to the Islamic army throughout the winter, in the hopes that the cold and harsh weather would force this army to retreat. It seems that the longevity of the siege and the exposure of the city to an earthquake drove them to appeal for reconciliation. The situation in Palestinian internal cities under siege wasn't quite different save they involuntarily surrendered, but the cities of northern Syria were stubborn because of their proximity to Byzantium, and more loyal than the cities of southern Syria, Jordan and Palestine ${ }^{(38) .}$

However, the position of these Christians changed after the defeat of the Byzantine Empire in the East, and the rest of them would seek peace with the Muslims in the next phase, and the people of Jerusalem accepted the reconciliation, to be in the presence of caliph Omar Ibn Al-Khattab to guarantee their rights ${ }^{(39)}$.As for the inhabitants of the coastal areas of the Levant, they were not completely subject to the conquerors until the final phase of the conquest, perhaps because the Byzantines provided them with supplies and troops by sea, which enabled their people to resist, and to pounce on them whenever they sensed fragility. As a result, Muslims established military bases to counter Byzantine attacks on those coasts under their control before the conquest ${ }^{(40)}$.

\section{The Forth Research: the Position of the Jews on the Islamic Conquest}

Some historical sources described the Position of the Jews on the Islamic Conquest as a welcoming attitude, not out of love for the Arabs, but out of spite for the Roman Empire and the Levant Christians. The relationship between Jews and the Byzantine Empire was described as bloody. After the spread of Christianity, Jews were affected by the official Christianity recognitionof theirChristian rivals, and in 248 A.D. they were excluded from civilian and military positions

${ }^{(41)}$.It appears from the terms of peace treaty signed between caliph Omar ibn al-Khattab and the Christians of Jerusalem (16 Ah/ $637 \mathrm{AD})$ the extent of tension between Jews and Christians, as it is stated that none of the Jews shall reside there ${ }^{(42)}$. Another indication that emphasizes the hatred of the Jews to the Roman is when Muslims retreated from Homs to the south and returned to the people of Homs their khraj after they learned the movements of the Roman army, the Jews stopped in the face of the Romans and said:

(30)Alazdi, op. cit., p. 238.

(31)Alazdi, op. cit., p. 326. ShukriFaisal, HarakatElfathElslami Fe El QarnElawal, Dar Al IlmLelmalayeen, Beirut, $1^{\text {st }}$ ed, 1974, p. 51.

(32)Alttabari, op. cit., chap. 3, p. 395 ..

(33)Alttabari, op. cit.,chap. 3, pp. 395, 400.

(34)Alttabari,op. cit.,chap. 3, p. 403.

(35)Faisal, op. cit., p. 52.

(36)NabihAqil, op. cit., p. 152.

(37)NabihAqil, op. cit., p. 171.

(38)NabihAqil, op. cit., pp. 171- 172.

(39)Alttabari, op. cit., chap. 3, p. 607.

(40)Alttabari, op. cit., chap. 4, p. 111.

(41)Khammash, op. cit., p. 72.

(42)Alttabari, op. cit., chap. 3, p. 609.

40 
"By Torah, the governor of Heraclius shall not enter the city of Homs until we get defeated and fatigued, they then locked the gates, and so did the Christians and Jews of the cities that reconciled ${ }^{(43)}$. A Jewish group, the Samaritan who inhabited Samaria (Nablus), a remnant of a Jewish sect lived for several centuries in Palestine on Mount Gerizim, the place the Lord chose for his servants as they claim ${ }^{(44)}$, were treated well, as the commander, Abu Obeida agreed with them on tribute to secure their lives and he granted them their land since they worked for Muslims as pathfinders and spies $^{(45)}$.This attitude of the Jewish minorities that lived in cities mostly inhabited by Christians had a special meaning; they found the Islamic conquest such an outlet that they supported the conquest to escape from the persecution of the Christian majority, which was supported by and dependent upon the Byzantine power ${ }^{(46)}$.

(43)Al-Baladhuri, op. cit., p. 143.

(44)SaiidFaraj Rashid, AlsamiryounWa Al Yahoud, Dar Almarreekh for Publishing, , AlarabyahAlso'odiyah, Riyadh,1987, p. $15,18$.

(45)Al-Baladhuri, op. cit., p. 158.

(46)A NabihAqil, op. cit., p. 173.

\section{Conclusion}

After studying the position of the Arab tribes and the population who settled in the Levant on the Islamic conquest, the study found:

1-The Arab tribes and other elements that stood by the fence were apprehensively waiting out of fear for who prevails.

2-The Arab tribes that converted to Christianity were not truly Christian and some of whom were forced to fight along the Romans in the war.

3-Jews welcomed Arab conquerors because of the poor relationship with the Roman Empire.

4-Some cities of the Levant showed resistance to the Islamic conquest, and the most resistant were the northern and coastal ones.

\section{Resources and References}

1-Abbas, Ihsan, Tareekh Bilad Esham, the University of Jordan Press, Amman - Jordan, 1990.

2- Azdi, Mohammed Ibn Abdullah (died. 170- 175 AH / 786-791 AD), Fottouh El Sham, innot, Essam Mustafa Oqla, Yousef Ahmed BaniYassin, Hamada Foundation for University Studies, Irbid, Jordan 2005.

3- Al-Baladhuri, Ahmed IbnYahya Al-Baladhuri (d. 279 AH / 892 AD) Fattouh El Boldan, innot: Mohammed Radwan, Dar AlkotobAlilmiah, Beirut, Lebanon, 1983.

4- Hugh Kennedy ,the Prophet and the Age of Caliphates, Longman London and New York.

5- Khammash, Nejdah, Al-sham Fe Sadr El Islam, Dar Tlass for Studies, Translation and Publishing, Damascus, 1st ed, 1987.

6- Khreisat, Mohamed Abdel-Kader, Dawr El Arab Almutanasira Fe El Fotouhat, the Fourth International Conference of the history of the Levant, the second seminar, vol. II.

7-NabihAqil, Mawqif Sokkan Bilad Elsham Min Alfath . Fourth International Conference on the history of the Levant, BiladEsham Fe Sadr El Islam, vol. III, University of Jordan, Amman, Jordan, 1987.

8-Nöldeke, Theodore, Umera'aGhassan, translated by Constantine Zurayk, Beirut 1939

9-Qudamah Ibn Jaafar (329 AH / 940 AD), AlkharajWaSena'at El Ketabah, explained commented by: Mohammed Hussein al-Zubaidi, the Ministry of Culture and Information, Iraq, 1981.

10-Saiid Faraj Rashid, AlsamiryounWa Al Yahoud, Dar Almarreekh for Publishing, , AlarabyahAlso'odiyah, Riyadh, 1987.

11-Shukri Faisal, HarakatElfathElslami Fe El QarnElawal, Dar Al IlmLelmalayeen, Beirut, 1st ed, 1974.

12-Alttabari, Abu Jafar, Muhammad IbnJarir (died. 310 AH / 922 AD), TareekhAlrosolWalMolouk, chap10, innot: Abou El Fadl Ibrahim, Dar Alma'aref

13-Yaqout Alhamwi, ShihabAlddinAlrumi (died. 626 AH / 1228 A, 2nd ed, 1995D), Mu'jamElboldan, Dar Saddir- Beirut 